\title{
The Electricity Crisis in Zambia: blackouts and social stratification in new mining towns
}

\section{by Rita Kesselring, Social Anthropology, University of Basel}

accepted version, author manuscript, published in Energy Research \& Social Science, no. 30: 94-102 available online at https://www.sciencedirect.com/science/article/pii/S2214629617301858

\section{Abstract}

In Zambia, privately-owned copper mines consume more than half of the electrical energy produced. By contrast, only $22 \%$ of private households are connected to the national grid. Against this background, the paper analyses energy distribution in Zambia's Northwestern Province, where new copper mines have opened following the hike in copper prices during the 2000's. Unlike rural families, residents in the three new urban centres in theory have access to electricity. Since 2015, however, the country suffers from an electricity crisis partly as a result of poor rainfalls in the $2014 / 2015$ season. In a situation of undersupply, the mine keeps unlimited access to electricity which privileges its operations and the housing areas. Daily blackouts for the rest of the town entrench existing inequalities and produce new ones. Based on long-term ethnographic research, the paper examines how electrical infrastructure and the possibility for forms of sociality relate both in the everyday and in the political discourse. I show how unequal electrical infrastructure contributes to the structuring of people into new social classes, and how, consequently, infrastructure is political from the start. By reflecting on the political and social consequences of unequal electricity supply, I provide preliminary thoughts on an energy distribution ethic.

\section{Introduction}

In the Republic of Zambia, 78\% of households are champions in using "green" substitutes to nuclear, coal or diesel generated power such as solar panels, wood and charcoal (Central Statistical Office Zambia 2013, 25). And unlike many of its neighbouring countries and countries in the global North, Zambia relies on hydropower for $94 \%$ of its electrical energy. However, this still raises critical questions about the ethics of energy systems. The problem is not so much environmental sustainability of production as justice of distribution: Mining companies use half of the country's electrical energy for their operations, while only $22 \%$ of households have access to electrical power.

Zambia usually has sufficient rainfall to fill its dams and sell surplus power to neighbouring countries. Until recently, electricity supply has never been considered as a problem in official discourse. This changed in 2015 when for the first time there was insufficient electricity to supply all customers. Cuts started to be inflicted onto domestic customers, so that today, in Gupta's words for India, "being connected to the grid and having electricity are two different issues" $(2015,559)$. As a result of poor rainfall in the 2014/2015 rainy season, electricity shortages, so-called "load shedding", now happen across the country and affect all actors - albeit unequally. Households which are not connected to the national grid are also indirectly affected by the power crisis, which, among other things let's prices for staple foods (such as maize and oil) rise and makes public services even less reliable. In 
addition to that, the commodity price boom which started in the early 2000s turned into a bust in 2015 again. Currently, the prices are down to about half of what they were at their peak in 2011. In combination with low global copper prices, energy shortages have affected Zambia's exports and the Kwacha's exchange rates. It has become clear that although hydro-electric power is a renewable source of energy, it is not necessarily a reliable source of energy (for a similar situation in Accra, Ghana, see Silver 2015). This situation does not affect all people equally; when electricity became scarcer, it also became even more unevenly distributed.

Although Zambia has a century-long history of extraction, the cases I consider in this article are new sites of mineral extraction. The empirical field of enquiry is the Solwezi region in the Northwestern Province of Zambia. In the region, three large-scale mines have been opened since 2003 in reaction to the recovery of global copper prices. Three new urban centres have developed around the three mines; the rest of the region consists of some peri-urban and mainly rural localities. Power lines and electrical power have only recently been introduced as an infrastructure to a large part of the area. Studying electrical power in this region is particularly interesting because we can witness the parallel development of rural electrification, an ordinary albeit slow process across the country, and massive electro-infrastructural development, that is "selectively territorialized investment" (Ferguson 2005) through private mining companies trying to secure unhindered extraction in selected onshore "enclaves" (Appel 2012a).

I conducted ethnographic research in the region for 14 months between 2013 and 2016, which included interviews and conversations with local state officials and mine employees, but most of all participant observation in the daily life of ordinary town dwellers in a rapidly urbanizing region. This research enables me to show how uneven access to electricity contributes to social stratification. I examine processes that result in the ordering of people into differentiated, hierarchically layered groups (social differentiation) whose members are aware of the discrepancy between them and members of another group (social stratification). While social differentiation is not necessarily a problem for the actors and groups involved, for it to be called social stratification, it requires their judgment. Infrastructure, as I will show, has constitutive power. Studying the ways in which lack of electric power affects social relations gives us clues about what might happen in the global North when ethical dilemmas of distribution rise in times of crisis, natural disaster, shortage or extreme increase of prices. To be sure, my aim here is not to reduce the global South to a testing ground for possible future scenarios in the global North. Rather, the focus on electricity as the key factor for a productive privatized extractive industry points to the reliance of the global North on the natural resources from the South (such as copper, cobalt and gold from Zambia), and the need to address questions of (re)distribution and sustainability with a global outlook. In other words, the politics of energy distribution on this extractive frontier of the global economy are affected not only by local 
and national forces, but by global forces as well. In this article, I thus propose to expand the focus of what we should be talking about when we think about the ethical implications of growing human reliance on electricity. I will propose some preliminary thoughts on an energy distribution ethics. After a brief overview of studies on electricity in the social sciences (1), I look at the energy and mining sector in Zambia (2) and in a new mining region (the Solwezi region) more specifically (3). I explore how planning processes of a new "company town", Kalumbila, and the expansion of the national grid contribute to social stratification (4). I then present ethnographic data on how urban residents deal with daily power outages in Solwezi town, an old administrative and since recently booming mine town (5). Unequal energy distribution and the power crisis provide everyday experiences of in- and exclusion. As such, it is a political and increasingly politicised topic, which turns into a source for ordinary town residents to criticize the local elite (6). In the conclusion (7), I provide some preliminary thoughts on a global energy distribution ethics.

\section{Electricity and Sociality}

Electrical infrastructure has been studied from a variety of scholarly perspectives, be it Deleuzeian, Foucauldian or with an ontological approach (Bennett 2005; Boyer 2015). ${ }^{1}$ While a large part of the literature on energy is based on the experience of the omnipresence of electrical energy in Western countries (Sovacool 2014, 22), many scholars have also criticized the underlying assumption that electricity is all pervasive, connects all spheres of everyday life, and that "we conveniently ignore whole electroscapes until something goes wrong" (Boyer 2015). By studying electricity in "imperfect" contexts, scholars point out the uneven geographies of urban energy networks (e.g. Luque-Ayala and Silver 2016a) and show parallels between uneven energy distribution and inequality in the global South (eg. Love and Garwood 2016; Gupta 2015; Winther 2016). Some researchers focus on the ways the idea of electricity as a public good triggers protest actions among those who do not have access to it (Alexandri and Chatzi 2016; Kirsch 2005, 2016; Schnitzler 2016); others focus on the relation between electricity and urban politics (Luque-Ayala and Silver 2016). My contribution draws on this critical corpus of studies of electricity networks that centres on inequality and power in relation to energy infrastructure.

Unsurprisingly, there is a number of studies examining a key characteristic of "imperfect" electrical power head-on: blackouts (cf. Silver 2015). In her article Circuits and Currents: Dynamics of disruption in New York City Blackouts, Rupp (2016) examines what happened during four blackouts in New York City between 1965 and 2012. She shows that blackouts produce some kind of liminality where

\footnotetext{
${ }^{1}$ For an overview of the ethnographic, anthropological and sociological literature on energy, see the introduction to this special issue (High and Smith, this issue), and for some challenges facing social scientific research on energy, see Stirling (2014).
} 
people start relating to one another differently. From this insight, she derives electricity's three main characteristics: it is invisible, indispensable and omnipresent. She then projects this emergent liminality during blackouts to bygone times. Before we were completely defined by the power of electricity, she argues, people lived as Mitmenschen (people living with one another). Today, we live as Nebenmenschen, that is alongside one another (Schütz 1967). ${ }^{2}$

I take the distinction between Mitmenschen and Nebenmenschen sociality as an analytical tool for lived relatedness, and examine how groups of people shift between Mitmenschen and Nebenmenschen relationships in light of the governing effects of electrical infrastructure. In Zambia, and in the broader Southern African region for that matter, where electricity is an emerging infrastructure (cf. Winther and Wilhite 2015), electric energy is visible, dispensable and faulty. In the contemporary Zambian context of faulty energy supply, human relations are most likely not as unproblematic as suggested for bygone times before complete electrification (cf. Platt 1991). In this article, I thus seek to track the role of electricity to help create forms of Mitmenschen and Nebenmenschen sociality.

Infrastructure is a manifestation of inequalities, domination and control, but it also helps to create forms of governance and social differentiation. Electricity play a crucial role in this process. I agree with Boyer's suggestion to expand Foucault's biopower with "energopower" (2014). To explore the effects of a faulty, unreliable and visible infrastructure and its relationship to governing attempts, I hence also draw on Latour (2007). With Latour, I understand energy as a socio-political and economic field "where any thing that does modify a state of affairs by making a difference" $(2007,71)$ must be considered. Electrical infrastructure plays a role in human interaction. Agency, as Latour suggests, springs from our interaction with human and non-human entities; a notion Barad confirmed as "intra-action" (2003). I take this insight into material efficacy as a starting point to focus on the creation of social groups through infrastructural governance processes, on the one hand, and the possibilities of relating to one another across these groups, on the other.

\section{Zambia's Energy and Mining Sector}

Ever since copper was first mined commercially in the late 1920s under the British South Africa Company, the mining sector has constituted the backbone of the economy in what today is Zambia. In the course of ninety years of industrialization and urbanization, poor and rural communities have often been removed from their homes to make space for large infrastructure projects. The most prominent example in Zambian history is the resettlement of approximately 57.000 people for the

\footnotetext{
${ }^{2}$ Gupta (2015) makes a similar argument for North Indian villages before electrification in the mid-1980s.
} 
construction of Kariba Dam in the 1950s, the then biggest man-made dam built to serve the mines in the Copperbelt (Colson 1971; McGregor 2009; Tischler 2013).

Today, the private large-scale copper mines are still the biggest consumers of electricity. Zambia has two main sources of electricity: the hydroelectric power plants at the Kafue Gorge and the Kariba Dam (Kariba North and Kariba North Bank Extension). Together, they produce about 94\% of Zambia's electricity supply (Energy Regulation Board 2016, 3); the rest comes from diesel, heavy fuel oil and solar generation plants. Poor rainfall during the 2014/2015 rainy season resulted in low dam water levels and consequently a considerable shortfall of supply of electricity. Another reason for lower energy production is poor generation capacity of the Kariba power plant. Firstly, state critics say that new Chinese turbines worked inefficiently, and, secondly, an increasingly unsound wall threatens the dam's stability and would urgently necessitate rehabilitation work. This came on top of economic challenges linked to a slump in copper prices, mainly due to sinking demand from China, which purchases about 40 percent of copper produced globally.

The main electricity provider, Zambia Electricity Supply Corporation Limited (ZESCO), was established in 1970 and the Government is the sole shareholder. ZESCO engages in cross-border trading of electricity through the Southern African Power Pool and bilateral markets. Typically, Zambia exports five times more electricity than it imports, but in 2014/2015, its power imports increased by more than 6000 percent (Energy Regulation Board 2016, 8). Amidst complaints about bad performance and inefficiency of state-run ZESCO, calls for privatization are on the rise. ${ }^{3}$ The Zambian government attempts to invest in new electrical infrastructure. Due to lack of funds, it tries to engage in publicprivate partnerships or looks for donor funding. The state tries to attract investors to set up solar projects for affordable electricity in rural areas (BMWi 2016). At the 2016 Annual Meeting of the African Development Bank in Lusaka (23 - 27 May 2016) under the theme of Energy and Climate Change, the delegate for Zambia, ZESCO's Managing Director, argued that “Lighting up and Powering Africa" - one of the ADB's five priority areas - could only become reality through public-private partnerships. ${ }^{4}$ Most recently, the Ministry of Energy started negotiations with China and Russia in relation to plans to set up nuclear energy infrastructure. ${ }^{5}$ Also, the European Union signed a €65million grant- co-financed with the European Investment Bank - to rehabilitate the low voltage distribution network and install new connections in the Lusaka City area. ${ }^{6}$ Up to 2017, however,

\footnotetext{
3 Late in 2016, the government announced its intention to privatise State Owned Enterprises including ZESCO, which was fiercely opposed by the unions. https://www.lusakatimes.com/2016/11/29/zesco-workers-oppose-pending-privatisation/ 4 http://www.afdb.org/en/annual-meetings-2016/

5 https://diggers.news/local/2017/05/17/zambia-moves-closer-to-nuclear-energy-production/ (Zambia moves closer to Nuclear energy production, 17 May 2017, News Diggers, online.

6 https://eeas.europa.eu/headquarters/headquarters-homepage/18954/european-union-signs-eu65-million-grant-zambiaimprove-access-energy_en
} 
these partnerships have only produced declarations of intent and could not revert the power crisis. Load shedding has the effect of a vicious circle, as it decreases production capacity which in turn leads to more load shedding.

In 2015 and 2016, planned and unplanned load shedding became the norm. Tariffs for domestic consumers increased (Energy Regulation Board 2016, 23), a decision which was first reversed by President Lungu in January 2016 when his election campaign for re-election in August 2016 started to gain momentum, but was approved by the Energy Regulation Board and implemented in May 2017. ${ }^{7}$ For the period between September to December 2015, for instance, there was a power deficit of around 560 to $1.000 \mathrm{MW}$ (peak demand would be $2.616 \mathrm{MW}$ ) (Energy Regulation Board 2016, 1). As a result, ZESCO increased the frequency and duration of load shedding. In 2015 and 2016, the majority of households, but also commercial and industrial consumers across the country, often experienced eight or more hours of power cuts per day. The mines are, however, largely exempt from cuts.

Mining constitutes the backbone of the Zambian economy. The country's economic history can be explained along fluctuations of global copper prices. Five years after independence in 1964, the mines were nationalized. Under the regime of the nationalized Zambia Consolidated Copper Mines (ZCCM), electricity was often free for workers and their families, together with water, education, health provision, transportation, and housing. In the 1970s, global copper prices dropped as a result of the oil crisis, and the Zambian state has since struggled to provide and maintain public infrastructure across the country. Between 1997 and 2002, as part of the World Bank Structural Adjustment Program, the state's ZCCM was unbundled into units and sold off to international investors in accordance with the new Mines and Minerals Act of 1995 (Fraser and Lungu 2007; Fraser and Larmer 2010). When the mines were sold to foreign investors, special 'development agreements' were signed between the state and the investors, containing provisions which later proved a hindrance to collect revenue (Lungu 2008). The provisions allowed mines to outsource some of the operations to contractors which directly led to casualization of workers. The companies were also exempt from payment of taxes on electricity for a certain period of time. Shortly after reprivatization of the mines in the early 2000s, the companies profited from China's growth and the ensuing high global copper prices. The mines mainly need electricity for providing underground mine ventilation, for hauling ore out of the ground, for crushing ore and extracting copper by electrolysis.

\footnotetext{
7 https://www.lusakatimes.com/2016/01/03/president-lungu-u-turns-on-new-electricity-tariffs/ In May 2017, the Energy Regulation Board approved ZESCO's application to increase electricity tariffs by $50 \%$ effective May 1, 2017, and $25 \%$ by September 1, 2017. The ERB's press statement can be accessed here: http://www.erb.org.zm/press/statements/tariffDecisionSpeech10.05.2017.pdf and the revised electricity tariffs effective on May 15 here: http://www.erb.org.zm/downloads/eregulation/erbApprovedTariffScheduleMay2017.pdf (last accessed May 17, 2017)
} 
The expansion of mining activities in the early 2000s possibly contributed to the power crisis. Most mines purchase energy from the Copperbelt Energy Corporation (CEC), which has a bulk supply agreement with ZESCO. ${ }^{8}$ CEC grew out of ZCCM in 1997 and is an independent company listed on the Lusaka Stock Exchange, which transmits energy purchased from ZESCO and distributes it to the mining industry on the Copperbelt and in the Northwestern Province at high voltage.

Even if they were connected to the grid, many Zambians cannot afford to pay for electricity, excluded from what McDonald (2008b) calls electric capitalism. Across Zambia, in rural and urban households, the main source used for lighting is the candle (27.7\% in 2010), followed by electricity from the public grid (22\%), paraffin (20.3\%) and solar power (2.9\%) (Central Statistical Office Zambia 2013, 25ff.). In rural households, electricity as a source of lighting is used by $3.1 \%$ of households only, contrary to $49.8 \%$ in urban areas. Across the Northwestern Province, only $8.1 \%$ of households use electricity for lighting. For cooking, wood is the main source of energy, used by $53.4 \%$ of households across Zambia, followed by charcoal (29.1\%) and electricity (16.9\%). In rural areas, cooking with wood (85\%) or charcoal (12.2\%) is even more widespread, while only $2.1 \%$ of rural households use electricity for preparing meals. In urban areas, electricity is used by $38.6 \%$ after charcoal $(53.9 \%)$ and before wood (7\%). Again, the Northwestern Province is below average in terms of its access to electricity; only $5.3 \%$ of households use electric power to cook their meals. These numbers show that farmers in the rural parts of the Solwezi region are generally grappling with the lack of access to electricity. For them, not having electric power to light or cook is rather normal.

While all households who have access to electricity were subject to load shedding, the mining sector further increased the differentiation between households and the mining sector. This favoured treatment is an expression of the sector's economic power and unequal access to decision makers. The mining sector is in fact one of the few sectors that increased its power consumption from 2014 to 2015 by $6.4 \%$. It consumed 54,5 , $\%$ of the total electricity in 2015 , followed by the domestic sector with 30,4\% (Energy Regulation Board 2016, 9).

\section{The Solwezi Region: a new mining area}

Across Zambia, the main urban areas are supplied with electricity through the national grid, while in some rural areas, electricity is mainly supplied by diesel generators run by ZESCO. The diesel power generation plants produce at high operative costs, do not have sufficient capacity for all the residents, are unreliable, and produce high gaseous emissions. Zambia thus not only faces a "severe power crisis" (BMWi 2016) in relation to current demand, but, according to the German Federal Ministry for Economic Affairs and Energy (BMWi 2016), should further expand its national grid to

${ }^{8}$ http://www.energyafrica.de/fileadmin/user_upload/Energy_Africa_15/Presentation_9th_German_African_Energy_Forum _2015_Copperbelt_Energy_Corporation_Zambia.pdf 
replace costly and environmentally unfriendly diesel power generation plants. The Northwestern Province is at the interface of two parallel, somewhat uncoordinated processes: rural electrification and the mining companies' own anxiety to secure sufficient supply for its operations.

The Northwestern Province is only partly connected to the national grid. There are three substations in the province: in Solwezi, Kasempa and Lumwana (see table 1). In 2012, the Zambia Environmental Management Agency (ZEMA) approved the connection of five more districts to the national grid at 132 kilovolts (kV). The power supply will originate from the two substations Kasempa (to Mufumbwe, Kabompo, Zambezi and Chavuma) and Lumwana (to Mwinilunga). ${ }^{9}$ Of the five districts, only Mwinilunga had been connected to the grid at the time of writing. ${ }^{10}$

The Northwestern Province, bordering on Angola to the west and on the DRC to the north, is a new mining province and host to three new large-scale mines which opened after 2003, following the rise in global copper prices. The Northwestern Province of Zambia has been a notoriously neglected region of every post-independence government (Peša 2014a, 2014b). The province has always been seen as an opposition region and was never a priority for the state house - neither under Kenneth Kaunda's one-party regime from 1973 to 1991 nor under any government or party since 1991. The opening of the mines happened against the backdrop of new technologies enabling the extraction of ore in this particular environment. The three new mines spread across an area of $140 \mathrm{~km}$; and each of the mines has spurred the growth of a town. ${ }^{11}$

\footnotetext{
9 EIA Decision Letter: Proposed Connection of North-western Province to the National Grid at 132 kV by ZESCO Limited, 4 January 2012.

10 In addition, a new district, which was formed by the statutory instrument in 2016, Mushindamo District, is also connected.

11 Up to last year, all of them were in one district, Solwezi District. But in late 2015, the large district was divided into three, the western of which, called Kalumbila District, now hosts Lumwana and Kalumbila mine. The second new district is called Mushindamo District, east of Solwezi.
} 


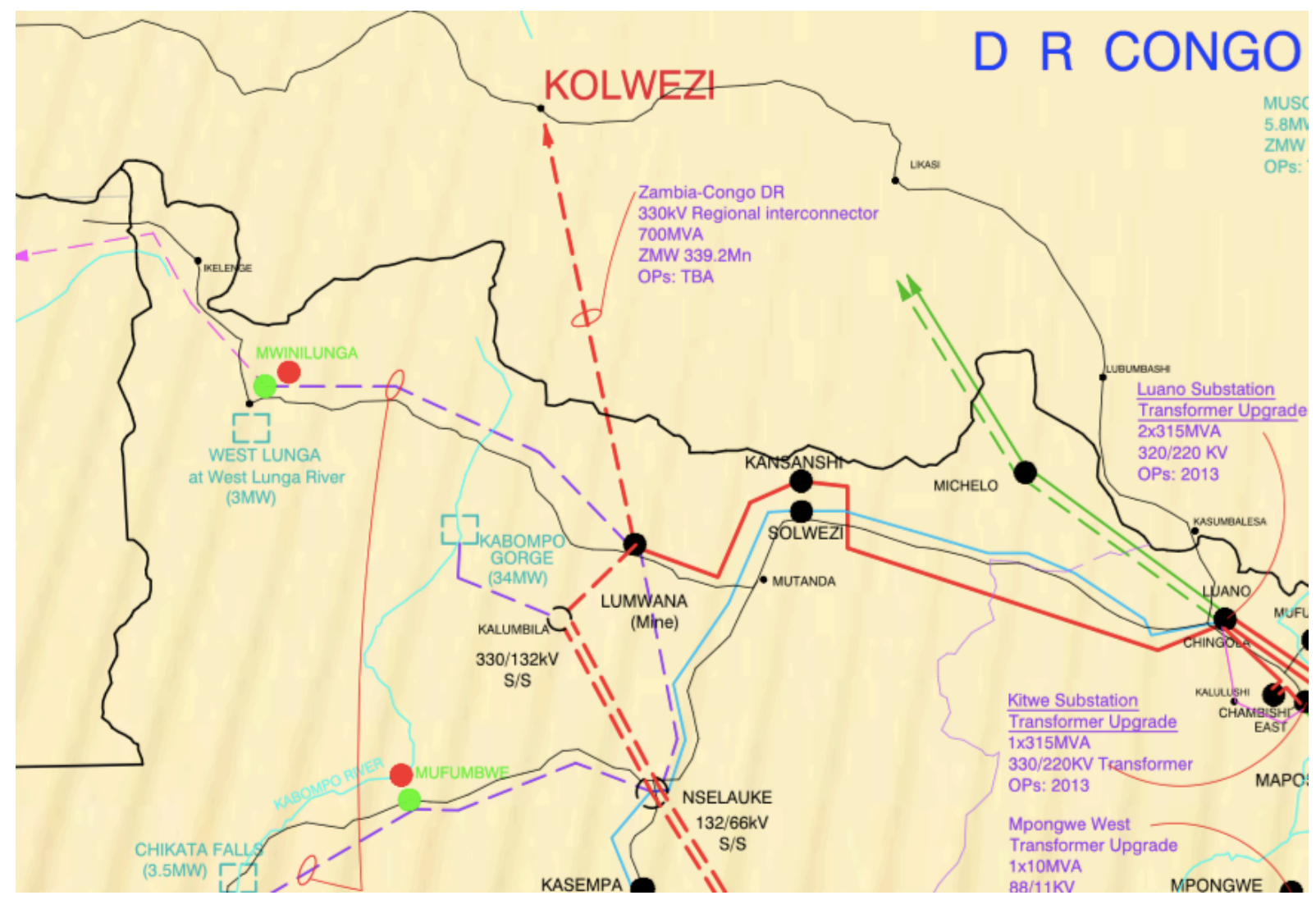

Table 1: http://www.eiz.org.zm/wp-content/uploads/2013/07/2013-10th-July-North-CPD-Presentatation-ZESCO.pdf

In this article, I look at two of the province's three towns, Solwezi and Kalumbila. Solwezi town was set up as a centre for the colonial administration in 1901 "to administer, service and support the mining function" (Maimbolwa 1980, 177) and today is the provincial capital of the Northwestern Province. Ten kilometres north of the centre of the town is Kansanshi Mine, an open-pit mine which laid dormant for almost a century. Kansanshi Mining PIc (KMP), 80\% owned by Canada-based First Quantum Minerals (FQM), is currently the biggest copper mine by output in Africa.

Within the past few years, Solwezi town has become a bustling, densely populated and rapidly expanding town (Negi 2009, 2010, 2011, 2014). For Zambians, economic liberalization brought insecurity, increased casualization of employment, reduced wages, and fierce competition for the few jobs left in what is growing into a highly mechanized industry (Fraser and Larmer 2010; Fraser and Lungu 2007; Mususa 2010, 2012). As a result of this, FQM's arrival in Solwezi spurred massive inmigration from other, older mining towns and from the rural areas. Solwezi town has grown from a $50^{\prime} 000$ to estimated $266^{\prime} 000$ inhabitants within the past ten years only (Preuss and SchmidtEisenlohr 2016, 61). The town has attracted business-minded persons and suppliers from the neighbouring province Copperbelt and other regions, and the opening of the mine also brought public and private infrastructure to the town: the tarring of some main public roads and the first Shoprite, a South African-owned supermarket (Negi 2009, 57). 
The national grid today extends to Lumwana mine further west but does not reach Kalumbila yet, the second town in which I conducted research. Kalumbila has a very different history and outlook from Solwezi. The town is a planned company town next to a new mine, the Sentinel copper mine which forms part of the larger Trident Project. The mine opened in a thinly populated area of small-scale cash-crop farming. Today, due to the influx of work seekers, it is a bustling centre in the region. In terms of electricity, the mine and the town still rely on its own diesel-driven plant that supplies roughly $200 \mathrm{MW}$ of electricity. At the time of writing, Kalumbila waits to be connected to the national grid through ZESCO.

The central state is, in theory, keen to develop this previously - and in large parts still - rural province, which is earmarked for economic growth in the mining, manufacturing, agricultural and even tourism sectors. On the one hand, however, it struggles to fund the region's development due to financial shortfalls and governance issues. On the other hand, we see a pattern of state-company relation at work in many countries with extractive industries (e.g. Welker 2014): the state holds back in putting money into the province arguing that the mines have an economic and social responsibility to take care of the residents where they operate. The companies argue that they pay taxes as part of their duty to help develop the country. In the Solwezi region, the result of Zambia's lopsided economy, also often uncritically referred to as 'resource curse' (Wengraf 2017), is the fact that the private, corporate investments are much more consequential for residents than the (local) state's. The Solwezi region represents a typical example of this, but it also presents the problem in a more accentuated manner due to rapid urbanization and a strong player in town: the mining company. To lay out the shift from social differentiation to social stratification facilitated and produced by electrical infrastructure, I now turn to a brief description of what happened in the Kalumbila area with the mine's arrival and the construction of a company town. In the Kalumbila area, one either has electricity or not, depending on where one lives. The mine and the company town have unlimited access to electricity; and there is no load shedding.

\section{Electricity in the Company Town Kalumbila}

In Kalumbila town and its surrounding area, the mining company has the biggest impact in terms of infrastructural development in general and electrification in particular. The fact that modern, mechanised mines need electricity to run their operations positions the company as an important governing actor in the area. The mines have a strong interest in the solution of the power crisis (only) to the degree that they can run their business uninterrupted. Even though the mining management 
mainly tries to make its company more efficient, their actions, like the building of a town for its workers, have the unintended consequence of increasing the stratification of communities. ${ }^{12}$ Approaching Kalumbila town, one passes by billboards and small paper boards tacked at trees reminding villagers to refrain from cutting down trees for the production of charcoal. With these and other measures, the mine frequently presents itself as "green". At the same time, however, it has rips open the ground for the extraction of copper for profit; dams water and pollutes groundwater; resettles hundreds of households; and generally introduces massive socio-economic change in an area which was previously rural and remote.

In Kalumbila, the formalization of the mine's license area is a pending issue (and an ongoing battle between various ministries). Despite this, the mine started with the construction of a large-scale open-pit Sentinel mine in 2012 and has since run it with costly diesel power plants. It would need, it says, 30\% more electricity to operate at full capacity. As ZESCO had not acted upon the company's pressure to connect it to the national grid, FQM took things into its own hand (as it often does with infrastructure indispensable for resource extraction) and built a $330 \mathrm{kV}, 600$ kilometres line across the country from the Southern Province through Central Province on its own costs (with the prospect of receiving favourable rates once ZESCO connects the power lines; see table 1). As of 2017, the lines are in place, only waiting for ZESCO's commissioning. One could judge this as the positive effect of a new mining area: the mine brings development to rural areas previously cut off from electrical power. Instead, what we see is the exacerbation of the inequalities that were already lingering as a result of the mine's arrival.

Based on my ethnographic research, I suggest that people living in the area can be spatially categorized into roughly four types of living conditions. Firstly, there is a state-of-the-art golf estate for the (mostly white) expatriate workers and the senior and junior management. I will describe life on a similar golf estate in the other town Solwezi below. The Kalumbila golf estate shares its main features where residents live a sheltered and privileged life with unlimited access to electricity, water, garbage collection, cleaning services, high-end private schools, sports and recreation areas and a club house at an artificial lake.

Secondly, the mine, through its Kalumbila Town Development Company (KTDC) started building Kalumbila town, designed by the Danish firm Gehl Architects for 10.000 houses of which a quarter have been built. Workers, both contracted and subcontracted and mostly men from the Copperbelt towns, live in houses which they rent from KTDC. Sometimes their families move with them; increasingly men are coming on their own, though, with no intention to permanently settle in the

\footnotetext{
12 Of course, the different departments represented in the management have different objectives (Welker 2014).
} 
town. KDTC's aim is to sell the houses to workers, but there is no bank in Zambia yet which would offer affordable mortgage. Residents enjoy access to electricity and water but have to pay for these services.

Thirdly, farmers, mostly Kaonde, Lunda or Luvale speaking, who lived in the mine's license and the town area were resettled into two small resettlement areas. They could choose whether to be closer to the main road and thus to business opportunities, or further south and thus closer to their original fields. The initial arrangement of the villages - loosely scattered, often shifting and along small pathways - has dramatically changed, especially in the northern resettlement area. The houses are densely arranged within a trapeze-formed zone. There is, like before, no running water or electricity. But unlike before, the areas are much more densely populated, boreholes to access water should cater for many more hundreds of people, and in-flux from often better educated work seekers from the Copperbelt towns limits space and economic opportunities for the original residents in the area. Finally, an initially small settlement, Chisasa, at a junction of the main road and the path to chief Musele's palace, has expanded in the past few years equally due to in-migration from the Copperbelt and other areas in the country. Thousands of work seekers, but also employees at the mine who do not want to spend their salaries on high rents in the company town, share the little infrastructure on land still under customary tenure. Hygiene is a pressing problem as there is neither running water nor electricity.

These four spatial entities are situated across a space of eight kilometre radius. This stark differentiation between living conditions, access to services, and chance for employment was introduced by the mine. In some instances, people were resettled and (albeit minimally) compensated; in most cases, people moved there by choice. However, the question of where to live and thus which services to access is not really a choice for most people. It depends on employment, and employment depends on education, which in turn is dependent on social status.

Cynically, the more "local" a person was, the worse off $s /$ he is now, except maybe for the chiefly family. One could also say that the mine's arrival spatially and socially segregated persons along their place in the production process. The owners of the means of production live outside the country (in Canada and Australia); the managers live on the golf estate and the capital; the workers live in a relatively modern and well serviced town; and the unemployed, the poor and most women and children live in the resettlement areas or in cramped informal compounds. To ameliorate some of the worst effects of the mine's doings, the mine rolls out corporate social responsibility (CSR) programs which remain selective but powerfully create new forms of dependencies (Dolan and Rajak 2016; Rajak 2011). 
The residents of these four spaces have an opinion about residents in the other spaces. In such articulations, electricity is often used to point out the difference between "them" and "us". For instance, an employee of one of the companies subcontracted by the mine, provided with a little house in Kalumbila town, once complained to me: "People living in the golf estate, they have many privileges. They get a car, airtime, they get their laundry done and the rooms are cleaned. Yes, life is hard here in Kalumbila town. And if they are off from work, they get on a plane." In contrast, a barber with a little shop in Chisasa complained that people living in Kalumbila town receive power for free. He has to load the batteries of the shavers with solar energy. During the loading, he can't take customers. Another example is a group of people from the resettlement area to the CSR office, which is responsible for all company-community relations, complaining about the lack of electricity. The CSR staffer was dismissive and challenged them to look at where they were before the mine came. Did they have electricity? No. Hence, there was no reason for the company to compensate them for something they did not have before. Although, from its perspective, they do not fall within CSR's responsibility, people living in the overcrowded, informal town of Chisasa also complained to the CSR office about missing electrification of the town. Again, the CSR office is dismissive saying that if the state's ZESCO finally expands the national grid to the mine and to Chisasa, they would also profit. But they will see, CSR staff predicted patronisingly, that rental prices will go up, and most residents will not be able to buy pre-paid electricity anyway.

For people in the resettlement area, recognizing the other's privilege is about more than the quest for electrification. Having access to electricity is the condition for the possibility to get a share of the profits. Many thousands were forced to give up their (communally administered) land, water and access to fields, giving up their lifestyles for some meagre compensation. The mine caused an increase of migrant labour in the area which constitutes a threat to the original residents' chances to profit from the new development in the area. Having electricity has real consequences. It means access to employment, knowledge, and mobility.

In general, comments like those above about the other are, I would argue, a sign - both symbolic and real - of estrangement. Having electricity or not divides people and prevents solidarity between the groups created through infrastructural development in the area. Through its acquisition of land and the de facto monopoly over paid work and electrical infrastructure, the mine has considerable power to shape the spatial and economic outlook of the region but also sociality between residential groups. The mine's exclusive provisioning of electrical power to its workers and the management structurates - along a gendered and racialized logic - residents of the area further. Hence, to complement Rupp's argument with a case study of an energy system which is almost antithetic to hers of New York city that lack of electricity might trigger a Mitmenschen sociality, I would say that 
unequal access to electrical infrastructure has estranged people - across groups - from each other rather than bringing them together, to the extent of stratifying people into new social groups.

\section{5.... And Off. Load Shedding in Solwezi Town}

In Kalumbila, the local state is hardly visible to soften the stark contrast between living conditions (even though a master plan for a municipal area close to Kalumbila town exists). The mine is more or less the sole governor in the region with intermittent conflicts with the local authorities, which are often resolved through the mine management's direct line to various ministries in the capital Lusaka. The current scarcity of electricity in the country, coupled with the mine's de facto planning authority makes processes of distribution precarious and cements social stratification possibly for years to come.

In Solwezi town, the electricity situation is different for two reasons. Firstly, the local state is and has been more present in shaping the infrastructural set-up of the town, and, secondly, residents across the suburbs are victims of load shedding. Unlike farmers in the Kalumbila area, urban residents in Solwezi, particularly labour migrants who come from the old Copperbelt towns further east, are used to electricity and its conveniences. They bemoan the lack of electricity and other infrastructure in some suburbs as proofs for the backwardness of the new, dusty mining town Solwezi. Countless times, I heard the phrase: "Solwezi is a bush".

This feeling of going backward instead of forward is greatly exacerbated by the energy crisis and load shedding. As a result of lack of access to electrical power and load shedding, urban residents revert to a number of alternative sources of energy in their daily lives. As mentioned above, cooking with wood or charcoal is extremely wide-spread (e.g. Mavhunga 2013); followed by solar panels, car batteries, and gas. People charge their cell phones at stalls; they listen to the radio with the help of a solar panel bought at the Chinese shop; and they generally use different sources of energy. Certainly, the ability to exploit different sources according to the need and availability is not to be romanticized. It has many consequences, the most important of which is the entrenchment of unequal gender relations within and beyond households. Many households do not buy electrical energy but rather have a young woman doing additional work, such as washing clothes. Load shedding also produces more work for aides, such as fetching water at a water kiosk when water pressure at the tap has receded due to lack of power. For one, this entrenches the pattern of gender relations where women do the household work. It is not only a gender issue but also a question of class, though. The young - often related - women are mostly from families which cannot afford to send their children to school.

While many urban residents are somehow coping with the lack of electric power and constant load shedding, a great many are severely limited in pursuing their income strategies and receiving public 
services. A number of individuals, businesses and institutions are dependent on electricity and cannot easily revert to other sources of power. Small and midsize businesses which rely on electric power suffer the most from power cuts. Meat or fish rots earlier; computers or printers need expensive backup systems; water supply becomes patchy when pumps stop working. As a result, prices for basic goods increase. Individuals who run a business must adjust their working rhythm to the power cuts, too. Professionals' laptops stop running once the battery is flat. A tailor would get up in the night when the bright light of the bulb she left on woke her and told her that power was back and start working on the sewing machine for the rest of the night. Pupils and students do their homework in candlelight which makes them sleepy earlier.

Power cuts also have massive effects on the quality of public services as provided by the municipal council to the residents of the town. The civic centre in Solwezi does have a generator but usually no cash for diesel to run it. When working at the Planning Department for a couple of months in 2015 as an intern, I realized that the council is organized along the assumption of constant flow of electricity. The offices are always packed with "clients", councillors or friends and relatives checking on the progress of their affairs. The council is simply not sufficiently staffed to deal with, say, the land disputes arising from the influx of migrants and the expansion of the mine's license area. There is also little bureaucratic continuity of how to file and archive these processes. More recently, software was introduced to help the decentralized units managing data and making it accessible across departments. Power cuts are thus jeopardizing an already ramshackle system of data organisation and storage. For town residents, load shedding has immediate effects. When power goes off, officers usually sit idle. This means that residents' dossiers are not worked on and they are put off for another day.

When there is no electricity for a while, water recedes, too, as the pumps need electricity. For many, lack of water is worse than lack of electricity (cf. Björkman 2015). ${ }^{13}$ The majority of Solwezi residents are not connected to water pipes but instead buy water from water kiosks run by the Northwestern Water and Sewerage Company, or get it from streams, hand-dug wells or community boreholes (Preuss and Schmidt-Eisenlohr 2016, 76-79). The latter are also drying up earlier in the year than usually because of low rainfall and the mine's extensive use of water to separate the copper from the ore. Indirect consequences of power cuts, no running water and further distances to fetch water, affect households and cement gender relations within families and communities.

A site where social differences are clearly visible is the golf course area. The privilege of the mining companies for almost unlimited access to electricity expands beyond its operations in the pit to where its senior and junior management and expat workers live. Although there is some

13 In 2015, a few cases of cholera were reported in Lusaka. 
differentiation among the management of the mine, too, their families live in a well-protected and guarded area situated literarily in the midst of a town struggling to provide services to its residents. About 200 people, including children, live on this so-called golf estate (others in the mine village within the license area), somewhere between the old centre of Solwezi Town and the mining area further north. The golf estate literally provides greener pastures and forms some kind of enclave (Appel 2012b, 2012a, 241; but see also Welker 2014, 79ff.). A river is dammed for pleasure and for water supply; the grass is green throughout the dry season; the houses are built with burnt, highquality bricks; and the private primary and secondary schools are striving to be the best in the country and in Southern Africa. Many residents are professionals from South Africa, Zimbabwe, Australia, New Zealand and other countries with a tradition and expertise in mining.

On which side of the guarded, electric fence one lives determines whether one has power cuts and running water, or not. To level this stark expression of inequality, the estate's management at some stage in 2016 introduced what they call a "solidarity cut". Three short, scheduled power cuts across the week were meant to show solidarity with the ordinary residents outside the golf estate. This was a purely artificial exercise not based on necessity; and it proved rather futile as it was incidentally introduced at a time when ordinary residents in Solwezi did not experience any cuts at all due to the pre-election phase (see below). Needless to say that such solidarity cuts do not contribute to redistribution of resources between the privileged and others. In fact, the latter did not even know about this demonstration of goodwill.

Residents at the golf estate not only live in an "extractive enclave" as Appel (2012) describes it for on- and offshore sites in Equatorial Guinea, but in an "energy enclave" that does not trigger Mitmenschen sociality between two social classes separated by an electric fence. Ironically, the solidarity cuts brought more guests into the estate's social venue, the Club, which has suffered from poor attendance by the estate's residents. This unintended consequence of increased engagement among often quarrelling families seems reminiscent of Rupp's description of New York neighbourhood sociality during blackouts.

In sum, residents of Solwezi town adjust their daily routines and work distribution within households to the recently introduced load shedding. Some are better positioned to do so than others. Overall, load shedding reinforces social differentiation in the everyday lives in a context where people are used to and dependent on electrical power and its benefits. When power goes off in the town planner's office, there is a brief moment of shared smirking at the supposedly incompetent political party in power, the Patriotic Front (PF). A minute later, however, power cuts have their immediate effects on each of them - differently. Moments of Mitmenschen sociality are short; the reality of a differentiated society kicks in quickly. Electricity has the potential to further stratify society: it makes 
people notice the difference between themselves and the other. This aspect of an energy distribution ethics becomes particularly visible when looking at how the energy crisis and energy distribution play out in the political realm, where I turn to now.

\section{The Politics of Energy Distribution}

While in theory load shedding seems to hit everybody except for the mine and its housing complexes, for people, this does not translate into an experience that everybody is the same. Only certain actors can make decisions about energy distribution, and the fact that load shedding and energy are distributed unequally is fodder for rumours and the basis for political moves. In what follows, I look at the ways in which energy provision is used as a tool by politicians and civil servants. The mining companies are usually protected from cuts or tariff hikes. When, in 2015 , the state announced that mines would also see $30 \%$ cuts in power supply, ${ }^{14}$ at a time when copper prices lingered near their six-year low, the mines threatened with the retrenchment of $30 \%$ of their labour force. This happened several times between 2015 and 2016. Usually, the state backtracked; in one instance, however, there were some cuts of the supply for the mines, and some hundred workers were indeed retrenched by the mines. ${ }^{15}$ Power cuts have real consequences, and the workers and their dependents bear the brunt of it.

Unsurprisingly, people point at inequalities with reference to power cuts and its consequences. In most cases, the energy discourse is an entry point for the political opposition to criticize the ruling party PF. The energy crisis in Zambia is not a clear-cut issue for many Zambians. While the state has reiterated continuously that the load shedding is due to climate change and low water levels in the reservoirs, people are not entirely sure about that. ${ }^{16}$ Many attribute it to mismanagement in the ZESCO board, suggesting that the energy company should be taken over by private investors. The fact that CEC does not cut power to the mines is seen as proof that private ownership would work better and more efficiently. For original residents of the Solwezi region, traditionally an opposition region, load shedding is a clear sign of the ruling party's failure to develop the country and instead robbing its citizens of public resources for personal gain. But even in Solwezi, there are many supporters of the ruling PF, some of which are working for the local state.

There is one suburb in Solwezi, the Stadium Area, where many civil servants live for reasons of accessibility to services and the size of plots and houses. Residents sceptical of the state's theory of

\footnotetext{
14 http://www.bloomberg.com/news/articles/2015-08-11/zambia-to-cut-copper-mines-power-supply-by-30-amid-shortage

15 http://mgafrica.com/article/2016-01-07-starved-of-electricity-first-quantum-to-cut-730-jobs-at-zambia-copper-mine

16 The official version is clear: power production is restricted due to low water levels. State officials have repeated this throughout 2015 and 2016, see for instance https://www.lusakatimes.com/2016/10/27/zesco-resumes-8-hour-loadshedding/ As an anthropologist, it is difficult for me to say anything meaningful on the topic except for pointing at what people say. I am not in a position to comment on what is essentially a technical question.
} 
low water levels would often point at this suburb. "During the night, Stadium Area has power, you can see it!". The fact that power is cut off along feeders is thus used to read the town through the lens of political favouritism.

Many instances feed people's suspicion that the issue is not the lack of water in the reservoirs. The time from late 2014, when President Michael Sata passed away in office, to early 2015 when President Edgar Lungu was elected as his successor in a fiercely contested election both within and outside the PF, right until August 2016 when regular elections took place, can be described as an uninterrupted phase of campaigning. Both Lungu and his main challenger, Hakainde Hichilema from the United Party for Social Development (UPND), visited Solwezi frequently as it grew into an important power base for either party. Whenever one of them was in town, load shedding stopped across town. People wondered how this was possible. Why can suddenly something be done against load shedding? And has the President a direct line to the ZESCO board to request for uninterrupted power supply? Surely, corruption must be at play here, opposition supporters tried to convince me. Feeding suspicion even more was the fact that about eight weeks before the regular, general elections on August 11,2016, the whole country experienced almost uninterrupted power supply. The rainy season 2015/2016 was certainly not capable of alleviating power shortages. Where, then, is power coming from? Pre-election rumours circulating among opposition supporters predicted a massive electricity tariff hike in case the PF would win again. This did not happen immediately, a fact which might be related to a tight and contested election outcome (Fraser 2016). In May 2017, however, the Energy Regulation Board approved ZESCO's application of a 75\% tariff adjustment to be effected in two phases (50\% effective on May 15 and 25\% on September 1, 2017). The tariff adjustment applies across all customers categories except for the mines. ${ }^{17}$

Faced with criticism of their performance, not surprisingly, the central state and local authorities try to solve the power crisis. Like in many other places in the world, electricity is a signifier of development (cf. Winther 2016) and rural and peri-urban communities aspire to be connected to the national grid. As Love and Garwood show for Alto Peru: "To have electricity is to be engaged with the broader world" $(2016,157)$. In the Solwezi region, the local authorities' aim is twofold: to produce more energy and to improve access to electricity for urban and rural households. Working towards a solution of the energy crisis brings its own problems, though. It is a technical task, but while pursuing it, more than mere technical implementation happens.

The local authorities, together with civil servants from ZESCO, have to make decisions as to who should profit first from the extension of the power lines. In Solwezi, a considerable number of new

${ }^{17}$ http://www.erb.org.zm/press/statements/tariffDecisionSpeech10.05.2017.pdf 
suburbs - or compounds - where most migrants settle are not connected to the grid at all, even though a high-voltage line connecting the substation with the mine soars above them (cf. Love and Garwood 2016, 159). This is similar to how the Gwembe Tonga people must have felt when Kariba Dam was built in Southern Zambia in the 1950s to feed the mines in the Copperbelt with energy. The resettled farmers saw the power line running across their villages and fields without the prospect of being integrated into "modernisation" (Tischler 2014). Many of the newly emerging compounds in Solwezi are not even on town land, but in areas under customary land tenure.

Rather than a broad rollout of basic services across the town, the council typically focuses on some identified key stakeholders in the governance of the region. This process is often driven by the elected councillors who are voted into council by their ward and tasked with bringing development into often remote areas. In committee meetings or in informal chats with civil servants, elected councillors campaign for attention of their own ward, and often clash with civil servants' rather exclusive attention on the urban areas. Elected councillors and officers share, however, the interest to have a good working relationship with chiefs and headmen, the main representatives of the traditional authorities in charge of the rural areas.

Solwezi town nestles in the middle of three chieftaincies (under chief Kapijimpanga, chief Mumena and senior chief Mujimanzovu), and the rapid expansion of the town into customary land makes them key stakeholders in the area. A chief lives and calls for meetings at his palace. Palaces are usually in very remote areas. Large efforts are thus made to bring electricity and other infrastructure to palaces. This of course reflects a long history of relation between administration and traditional authorities: a chief is mollified through gifts (Negi 2010). Potentially, though, an energized palace benefits the communities living around the palace. The lines, however, also pass by hundreds of homesteads and villages which do not benefit from rural electrification.

In sum, the distribution of access to electricity is a political issue not only from an analytical perspective but also for residents. Given the visibility of electrical infrastructure (lit suburbs, street lamps, power lines above one's head, etc.), the energy discourse becomes tangible. Electricity thus makes differences visible, exacerbates them, and offers an entry point for criticism of the elite.

\section{An Energy Distribution Ethics}

Over the two years of energy crisis in Zambia, energy ethics have been increasingly formulated as a social class critique. Criticism of current distribution among groups, across suburbs, between the town and the mine, expats and Zambians, etc., pop up here and there in subtle ways not always easy to be recognized as a criticism of the status quo. Most critical voices are articulated along party political lines. Some of the critical voices extend beyond better service provision to redistribution. When people comment on a group socially perceived as different by pointing out their privileges, this 
is already a sign of stratification, preventing Mitmenschen sociality. I tried to show that these processes of separating people from one another are to a considerable extent produced through infrastructural things. Fences are obvious, electricity is subtler. For both it is true that things are more than symbols of privilege or neglect (Larkin 2013); they change status and enable or disable certain forms of sociality, which in turn may be the seed for political action.

This socio-material energy assemblage - made up of practices, discourse and institutions; and humans and things - as I describe it in the article is both localized and bound to a geopolitical locale but also a direct product of the global economy and historically grown transnational power relations. Although my interlocutors are fully aware of the political economy of extractivism, to a certain extent, the mining sector manages to appropriate public discourses on development and to silence criticism against its extractivist and detached mode of business.

Added to its dependency on the global commodity markets, Zambia, like most countries in Southern Africa, faces drought and water scarcity, both outcomes of global warming that dramatically reduce electricity supply within Zambia and in the region. Sovacool's first of three moral questions - "Are we being fair to the present generations in giving some people disproportionate access to the benefits of energy while giving others its burdens?" (Sovacool 2013, 2) - is thus immanently important here. The current electricity crisis in Zambia serves as a warning sign beyond Zambia of what might happen when energy supply is short and when questions of distributions are left out for too long: power relations are cemented and social stratification of society increases.

An energy ethics must from the very beginning include the question of distribution. We cannot come up with a distribution key on a national level alone, though- just as sustainability cannot be solved on one continent only, and just as extractivism has always been a global endeavour.

\section{References}

Alexandri, Georgia, and Venetia Chatzi. 2016. 'Athens: Switching the Power Off, Turning the Power On - Urban Crisis and Emergent Protest Practices'. In Energy, Power and Protest on the Urban Grid: Geographies of the Electric City, edited by Andrés Luque-Ayala and Jonathan Silver, 197-212. London: Routledge.

Appel, Hannah. 2012a. 'Walls and White Elephants: Oil Extraction, Responsibility, and Infrastructural Violence in Equatorial Guinea'. Ethnography 13 (4): 439-65.

- - . 2012b. 'Offshore Work: Oil, Modularity, and the How of Capitalism in Equatorial Guinea'. American Ethnologist 39 (4): 692-709.

Barad, Karen. 2003. 'Posthumanist Performativity: Toward an Understanding of How Matter Comes to Matter'. Signs: Journal of Women in Culture and Society 28 (3): 801-31.

Bennett, Jane. 2005. 'The Agency of Assemblages and the North American Backout'. Public Culture 17 (3): 445-65.

Björkman, Lisa. 2015. Pipe Politics, Contested Waters: Embedded Infrastructures of Millennial Mumbai. Durham: Duke University Press Books.

BMWi. 2016. 'Subsector Analysis: Zambia. The Power Crisis and Its Consequences for Solar Energy in 
the Zambian Mining Sector'. Berlin: Federal Ministry of Economic Affairs and Energy BMWi.

Boyer, Dominic. 2014. 'Energopower: An Introduction'. Anthropological Quarterly 87 (2): 309.

- - . 2015. 'Anthropology Electric'. Cultural Anthropology 30 (4): 531-39.

Central Statistical Office Zambia. 2013. 'Zambia 2010 Census of Population and Housing. Report on Characteristics of Households and Housing'. Lusaka: Central Statistical Office.

Colson, Elizabeth. 1971. The Social Consequences of Resettlement: The Impact of the Kariba Resettlement Upon the Gwembe Tonga. Manchester: Manchester University Press.

Dolan, Catherine, and Dinah Rajak, eds. 2016. The Antropology of Coporate Social Responsibility. New York: Berghahn Books.

Energy Regulation Board. 2016. 'Energy Sector Report 2015'. Lusaka: Energy Regulation Board.

Ferguson, James. 2005. 'Seeing like an Oil Company: Space, Security, and Global Capital in Neoliberal Africa'. American Anthropologist 107 (3): 377-82.

Fraser, Alastair. 2016. 'Zambian Democracy: All Heat, No Light'. ROAPE. September 1.

http://roape.net/2016/09/01/zambian-democracy-heat-no-light/ (last accessed June 5, 2017).

Fraser, Alastair, and Miles Larmer, eds. 2010. Zambia, Mining, and Neoliberalism: Boom and Bust on the Globalized Copperbelt. Africa Connects. New York: Palgrave Macmillan.

Fraser, Alastair, and John Lungu. 2007. For Whom the Windfalls? Winners \& Losers in the

Privatisation of Zambia's Copper Mines. Civil Society Trade Network of Zambia / Catholic Centre for Justice, Development and Peace.

Gupta, Akhil. 2015. 'An Anthropology of Electricity from the Global South'. Cultural Anthropology 30 (4): 555-68.

High, Mette M., and Jessica Smith. 2017. 'Exploring the Anthropology of Energy: Ethnography, Energy and Ethics'. Energy Research \& Social Science Special Issue Exploring the Anthropology of Energy: Ethnography, Energy and Ethics.

Kirsch, Thomas. 2005. 'Illegal Connections. Conflicts over Electricity in Soweto, South Africa'. Soziale Welt 16 (September): 193-208.

- - . 2016. 'Tapping Wires, Cutting Cables: Electricity and Infrastructure Theft in South Africa'. In Up Up: Stories of Johannesburg's Highrises, edited by Nele Dechmann, 86-98. Ostfildern: Hatje Cantz Verlag.

Larkin, Brian. 2013. 'The Politics and Poetics of Infrastructure'. Annual Review of Anthropology 42 (1): 327-43.

Latour, Bruno. 2007. Reassembling the Social: An Introduction to Actor-Network-Theory. New Ed.

Oxford University Press, USA.

Love, Thomas, and Anna Garwood. 2016. 'Electrifying Transitions: Power and Culture in Rural Cajamarca, Peru'. In Cultures of Energy: Power, Practices, Technologies, edited by Sarah Strauss, Stephanie Rupp, and Thomas Love, 147-63. London: Routledge.

Lungu, John. 2008. 'Copper Mining Agreements in Zambia: Renegotiation or Law Reform?' Review of African Political Economy 35 (117): 403-15.

Luque-Ayala, Andrés, and Jonathan Silver, eds. 2016. Energy, Power and Protest on the Urban Grid: Geographies of the Electric City. London: Routledge.

Maimbolwa, M.M. 1980. 'Urban Growth in North-Western Province'. In Handbook to the NorthWestern Province 1980, edited by David S. Johnson, 175-90. Z.G.A. Regional Handbook Series 8. Lusaka: Zambia Geographical Association.

Mavhunga, Clapperton Chakanetsa. 2013. 'Cidades Esfumaçadas: Energy and the Rural-Urban Connection in Mozambique'. Public Culture 25 (2 70): 261-71.

McDonald, David, ed. 2008. Electric Capitalism: Recolonising Africa on the Power Grid. Pretoria: HSRC Press.

McGregor, JoAnn. 2009. Crossing the Zambezi: The Politics of Landscape on a Central African Frontier. 
Harare, Zimbabwe: James Currey.

Mususa, Patience. 2010. "'Getting by": Life on the Copperbelt after the Privatisation of the Zambia Consolidated Copper Mines'. Social Dynamics 36 (2): 380-94.

- - . 2012. 'Topping Up: Life Amidst Hardship and Death on the Copperbelt'. African Studies 71 (2): 304-22.

Negi, Rohit. 2009. 'Copper Capitalism Today: Space, State and Development in North Western Zambia'. Unpublished PhD Dissertation, Ohio: The Ohio State University.

- - - 2010. 'The Mining Boom, Capital and Chiefs in the "New Copperbelt"'. In Zambia, Mining, and Neoliberalism: Boom and Bust on the Globalized Copperbelt, edited by Alastair Fraser and Miles Larmer, 209-36. Africa Connects. New York: Palgrave Macmillan.

- - . 2011. 'The Micropolitics of Mining and Development in Zambia: Insights from the Northwestern Province'. African Studies Quarterly 12 (2): 27-44.

---. 2014. “'Solwezi Mabanga": Ambivalent Developments on Zambia's New Mining Frontier'. Journal of Southern African Studies 40 (5): 999-1013.

Peša, Iva. 2014a. 'Moving along the Roadside: A Social History of Mwinilunga District, 1870s-1970s'. Unpublished PhD Dissertation, Leiden: Leiden University.

https://openaccess.leidenuniv.nl/handle/1887/28744 (last accessed June 5, 2017).

- - . 2014b. "'We Have Killed This Animal Together, May I Also Have a Share?” Local-National Political Dynamics in Mwinilunga District, Zambia, 1950s-1970s'. Journal of Southern African Studies 40 (5): 925-41.

Platt, Harold L. 1991. The Electric City: Energy and the Growth of the Chicago Area, 1880-1930.

Chicago: University of Chicago Press.

Preuss, Lena, and Daniel Schmidt-Eisenlohr. 2016. 'Final Report Solwezi Urban Baseline Study'. Lusaka: GIZ.

Rajak, Dinah. 2011. In Good Company: An Anatomy of Corporate Social Responsibility. Stanford: Stanford University Press.

Rupp, Stephanie. 2016. 'Circuits and Currents: Dynamics of Disruption in New York City Blackouts'. Economic Anthropology 3 (1): 106-18.

Schnitzler, Anita. 2016. Democracy's Infrastructure: Techno-Politics and Protest after Apartheid. Princeton: Princeton University Press.

Schütz, Alfred. 1967. The Phenomenology of the Social World. Evanston, Illinios: Northwestern University Press.

Silver, Jonathan. 2015. 'Disrupted Infrastructures: An Urban Political Ecology of Interrupted Electricity in Accra'. International Journal of Urban and Regional Research 39 (5): 984-1003.

Sovacool, Benjamin. 2013. 'Introduction'. In Energy and Ethics: Justice and the Global Energy Challenge, edited by Benjamin Sovacool, 1-15. New York: Palgrave Macmillan.

- - . 2014. 'What Are We Doing Here? Analyzing Fifteen Years of Energy Scholarship and Proposing a Social Science Research Agenda'. Energy Research \& Social Science 1: 1-29.

Stirling, Andy. 2014. 'Transforming Power: Social Science and the Politics of Energy Choices'. Energy Research \& Social Science 1: 83-95.

Tischler, Julia. 2013. Light and Power for a Multiracial Nation: The Kariba Dam Scheme in the Central African Federation. Cambridge Imperial and Post-Colonial Studies Series. New York: Palgrave Macmillan.

- - . 2014. 'Cementing Uneven Development: The Central African Federation and the Kariba Dam Scheme'. Journal of Southern African Studies 40 (5): 1047-64.

Welker, Marina. 2014. Enacting the Corporation: An American Mining Firm in Post-Authoritarian Indonesia. Berkeley: Univ of California Press.

Wengraf, Lee. 2017. 'The Pillage Continues: Debunking the Resource Curse'. ROAPE. January 24. 
http://roape.net/2017/01/24/pillage-continues-debunking-resource-curse/ (last accessed June 5, 2017).

Winther, Tanja. 2016. 'Space, Time, and Sociomaterial Relationships: Moral Aspects of the Arrival of Electricity in Rural Zanzibar'. In Cultures of Energy: Power, Practices, Technologies, edited by Sarah Strauss, Stephanie Rupp, and Thomas Love, 164-76. London: Routledge.

Winther, Tanja, and Harold Wilhite. 2015. 'Tentacles of Modernity: Why Electricity Needs Anthropology'. Cultural Anthropology 30 (4): 569-77. 